\title{
SOME ELECTRICAL PROPERTIES OF THE SLOW POTENTIAL CHANGES RECORDED FROM THE GUINEA PIG STOMACH IN RELATION TO DRUG ACTIONS
}

\author{
Tetsuo Magaribuchi, Teruyoshi Ohbu, Yasuzi SaKamoto, and \\ Yasushi Yамамото \\ Department of Physiology, Faculty of Dentistry, Kyushu University, Fukuoka, Japan
}

Summary 1) Properties of the slow potential changes recorded from antral and pyloric regions of the guinea pig stomach were investigated with both the double sucrose gap and microelectrode methods.

2) Frequency, amplitude, and duration of the slow potential changes varied from 2 to 5 per $\mathrm{min}, 0$ to $30 \mathrm{mV}$, and 6 to $14 \mathrm{sec}$.

3) During the slow potentials, membrane resistance was reduced. This reduction exceeded that caused by the rectifying property of the membrane.

4) The amplitude of the slow potential was enhanced by application of weak inward current pulses and decreased during weak outward current pulses.

5) The frequency of the slow potential changes was a function of the temperature. The $\mathrm{Q}_{10}$ value was 3.2.

6) Na-deficient $(1 / 10 \mathrm{Na}) \mathrm{Krebs}$ solution suppressed the slow potential changes, but they were restored by conditioning hyperpolarization of the membrane. However, in Na-free solution the slow potential changes were generated with neither normal nor hyperpolarized membrane.

7) In low K- and low Ca-Krebs solutions, the amplitude and frequency of the slow potential changes were reduced.

8) When $\mathrm{Cl}$ ion was replaced by the less permeable $\mathrm{C}_{6} \mathrm{H}_{5} \mathrm{SO}_{3}$ ion, the slow potential change was abolished completely. When $\mathrm{Cl}$ ion was substituted with $\mathrm{Br}$ ion, the frequency of the slow potential was not reduced, and in some preparations it was increased.

9) $\mathrm{Ba}$ ion in the presence of $\mathrm{Ca}$ ion increased the frequency of the slow potential changes, but in the absence of $\mathrm{Ca}$ ion the frequency was not increased. Sr ion could not be substituted for $\mathrm{Ca}$ ion in the generation of the slow potential changes.

Received for Publication February 14, 1972

曲淵徹雄, 大部彰義, 坂本康二, 山本 泰 
10) Prostigmin $\left(10^{-6} \mathrm{~g} / \mathrm{ml}\right)$, atropine $\left(10^{-6} \mathrm{~g} / \mathrm{ml}\right)$, and tetrodotoxin $\left(10^{-6} \mathrm{~g} / \mathrm{ml}\right)$ modified the frequency of the slow potential changes. However, the effects of these drugs were inconsistent.

11) Acetylcholine $\left(10^{-7} \mathrm{~g} / \mathrm{ml}\right)$ increased the frequency of the slow potential changes. At a concentration of $10^{-6} \mathrm{~g} / \mathrm{ml}$, acetylcholine depolarized the membrane to a level above the peak of the slow potential changes. Conditioning polarization of the membrane in steps proportionally enlarged the amplitude of the depolarizations in steps.

12) Catecholamines (noradrenaline and isoprenaline) suppressed the generation of the slow potential changes. Noradrenaline $\left(10^{-6} \mathrm{~g} / \mathrm{ml}\right)$ increased the membrane potential, reduced the membrane resistance, and abolished the slow potential changes. Isoprenaline $\left(10^{-6} \mathrm{~g} / \mathrm{ml}\right)$ only slightly hyperpolarized the membrane and did not reduce the membrane resistance. The effect of noradrenaline was almost completely blocked by phentolamine $\left(10^{-6} \mathrm{~g} / \mathrm{ml}\right)$.

Two types of membrane activity were recorded with external and internal electrodes from the smooth muscle cells of the gastrointestinal canal. One type was called basic electric rhythm (BER by Alvarez and MAHONEY, 1922) or slow wave (slow potential change) and is an oscillating potential change with a frequency of 4 to 5 per min in the case of the dog antrum. The other, called spike potentials, may occur as single or multiple oscillations (BORTOFF, 1967; BASS, 1965; Daniel, 1965; Prosser and Bortoff, 1968).

DANIEL (1965) found that in the active antrum of the dog the repetitive initial spike potential was followed by a second negative going potential (prolonged secondary depolarization corresponding to BER) or by repetitive negative going spikes in the terminal antrum. Adrenergic amines abolished the second potential and contraction, and cholinergic drugs initiated or enhanced the second potential and contractions. These drug effects on the membrane activity were abolished by pretreatment with atropine.

PAPASOVA et al. (1968) studied the cat stomach using intra- and extracellular recording methods and described spontaneous activity with slow waves and spikes in vitro. The slow wave consisted of an initial rapid component which was Nadependent, propagated, and not correlated with contraction, and a second slow component which was Ca-dependent, abolished by Mn ion, probably not propagated, but always found when contraction occurred. Spikes sometimes appeared on the second component and enhanced contractions.

Slow waves and spikes have also been recorded from the antral regions of guinea pig stomach with an intracellular recording electrode (KURIYAMA et al., 1970).

The double sucrose gap method has been successfully applied to measure the membrane activity of the various visceral smooth muscles (BERGER, 1963; 
Brading et al., 1969; Bülbring and Tomita, 1969; KuriYAma and Tomita, 1970). The present experiments were intended to analyze the electrical properties of the slow potential changes recorded from the circular muscle of antrum with the double sucrose gap method.

\section{METHODS}

Guinea pigs weighing 200-250 g were stunned and bled. The stomach was excised and dissected. The connective tissue and mucous layer were removed carefully in Krebs solution at room temperature. A strip of the circular muscle $0.8-1.2 \mathrm{~mm}$ wide and $25-30 \mathrm{~mm}$ long with attached longitudinal muscle was dissected. The double sucrose gap method employed was the same as that described by KuriYama and Tomita (1970), SAKamoto and KuriYama (1971), and MAgaribuchi et al., (1971). Some experiments were carried out by microelectrode method.

A modified Krebs solution of the following composition was used (mM): $\mathrm{Na}^{+}, 137.4 ; \mathrm{K}^{+}, 5.9 ; \mathrm{Mg}^{++}, 1.2 ; \mathrm{Ca}^{++}, 2.5 ; \mathrm{Cl}^{-}, 134.0 ; \mathrm{HCO}_{3}{ }^{-}, 15.5 ; \mathrm{H}_{2} \mathrm{PO}_{4}^{-}$, 1.2; and glucose, 11.5; equilibrated with $97 \% \mathrm{O}_{2}$ and $3 \% \mathrm{CO}_{2}$. As a substitute for $\mathrm{Na}^{+}$, Tris (hydroxymethyl aminomethane), $\mathrm{Li}^{+}$, and sucrose were used. When Na-free solution was prepared, $\mathrm{NaCl}$ and $\mathrm{NaHCO}_{3}$ were omitted and $\mathrm{KCl}$ (4.7 mM) was replaced with $\mathrm{KHCO}_{3}$. The $\mathrm{pH}$ of the Na-free solution was adjusted to 7.2-7.3 with Tris buffer. As a substitute for chloride, $\mathrm{NO}_{3}^{-}, \mathrm{Br}^{-}$, and $\mathrm{C}_{6} \mathrm{H}_{5} \mathrm{SO}_{3}^{-}$ were used. However, in all solutions $7.4 \mathrm{mM} \mathrm{Cl}^{-}$remained as $\mathrm{CaCl}_{2}$ and $\mathrm{MgCl}_{2}$. Isometric tension was recorded simultaneously with membrane activity with a strain gauge. The experiments were carried out at $32 \pm 2{ }^{\circ} \mathrm{C}$. For the application of drugs, one end of a small vinyl tubule was attached to the injection syringe $(1 \mathrm{ml})$. Drugs were diluted to the required concentration with the test solution. By this procedure, $0.1 \mathrm{ml}$ of injected drugs were in contact with the tissue for only 2-3 sec. The principal drugs used were tetrodotoxin (Sankyo Pharm. Co.), atropine sulphate (Tanabe Pharm. Co.), acetylcholine chloride (Daiichi Pharm. Co.), prostigmin (neostigmine) methylsulphate (Sionogi Pharm. Co.), 1-noradrenaline (Sigma Chem.), 1-isoprenalime hydrochloride (Nikken Chem.), phentolamine mesylate (Ciba), and propranolol hydrochloride (I. C. I.). The concentrations of drugs used in the experiment are described in the results and indicate the final concentration.

\section{RESULTS}

General pattern of the slow potential changes recorded by microelectrode and double sucrose gap

When a microelectrode was inserted into the smooth muscle cell of the circular muscle in the antral region, slow potential changes could be recorded. Most 
of the smooth muscle fibers generated slow depolarizations with a duration of 8 to $13 \mathrm{sec}$, amplitude of a few $\mathrm{mV}$ to $40 \mathrm{mV}$, and frequency of 3 to 6 per min at $35^{\circ} \mathrm{C}$. When the preparation was excised from the pyloric region, the slow potentials appeared with higher frequency (5-9 per min). On the other hand, when the tissue was excised from above the antrum near the fundus, slow waves were rare.

A spike often appeared on the slow depolarization generated from the antral and pyloric regions. However, it did not appear consistently. Furthermore, the spike did not always have an overshoot. The amplitude of the spike from the resting potential level ranged from $38-64 \mathrm{mV}$, and the maximum rate of rise of the spike was $3.2-6.8 \mathrm{~V} / \mathrm{sec}$. These observations are in agreement with those reported by previous investigators (KuriYama et al., 1970).

Similar potential changes were recorded from the smooth muscles of the pyloric region of the stomach using the double sucrose gap method. Generation of a spike on the slow potential change was rare, and the frequency of the slow potential changes ranged between 2 and 5 per min. The amplitude and duration
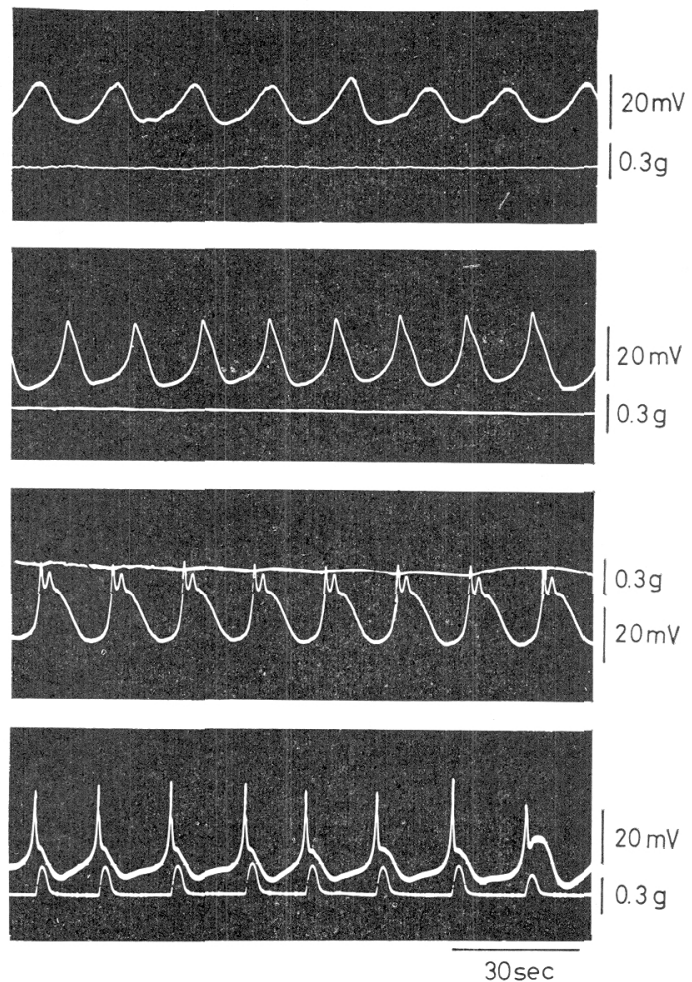

Fig. 1. Various patterns of the slow potential changes recorded with double sucrose gap from circular muscle of the stomach. 
of the slow potential changes varied from a few $\mathrm{mV}$ to $30 \mathrm{mV}$ and from $6 \mathrm{sec}$ to $14 \mathrm{sec}$, respectively.

The circular muscle preparation used in the present experiments contained longitudinal muscle, but preparations dissected from the pure circular muscle layer of the pyloric region also generated slow potential changes. Figure 1 shows the spontaneously generated slow potential changes with and without spikes taken from the circular muscle preparations. The slow potential can therefore be generated by the pure circular muscle layer as well as by the longitudinal layer (KuRIYAMA et al., 1970).

Effects of electrical stimulation and temperature on the spontaneously generated slow potential changes

Membrane resistance during the generation of the slow potential change was measured by application of short inward current pulses $(500 \mathrm{msec}, 0.5 \mathrm{~Hz}$ ). As shown in Fig. 2a, at the peak depolarization of the membrane, membrane resistance was reduced to $0.3-0.2$ times the membrane resistance observed at the resting level of the membrane potential. This result, however, may not indicate that the slow potential changes were due to increase of ionic permeability, since rectification of the membrane was observed in the longitudinal muscle of the stomach when it was depolarized (Kuriyama et al., 1970). When current and voltage relationships were examined in circular muscle, marked rectification of the membrane was
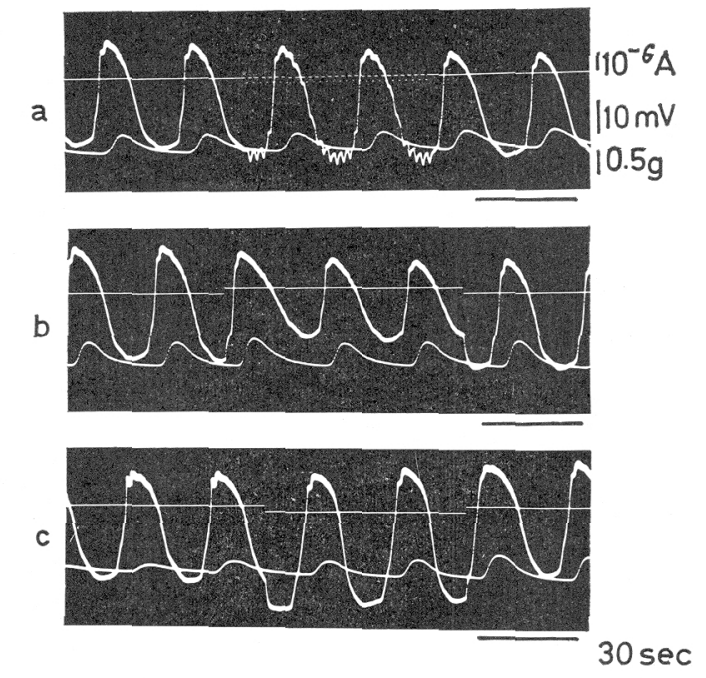

Fig. 2. Effects of electrical stimulation on the slow potential changes. (a) Application of short inward current pulses $(500 \mathrm{msec} 0.5 \mathrm{~Hz})$. (b) Weak outward current $(73 \mathrm{sec})$. (c) Weak inward current $(60 \mathrm{sec})$. Top trace: intensity of the applied current. Middle trace: electrical activity. Bottom trace: mechanical activity. 
observed during depolarization by $4-12 \mathrm{mV}(n=5)$. However, the ratio of the membrane resistance in the resting condition and in the depolarized membrane was only $0.6-0.4(n=5)$. The reduction of the membrane resistance during the peak of the slow potential changes was therefore not solely due to the rectifying property of the membrane but probably mainly due to increased ionic conductance.

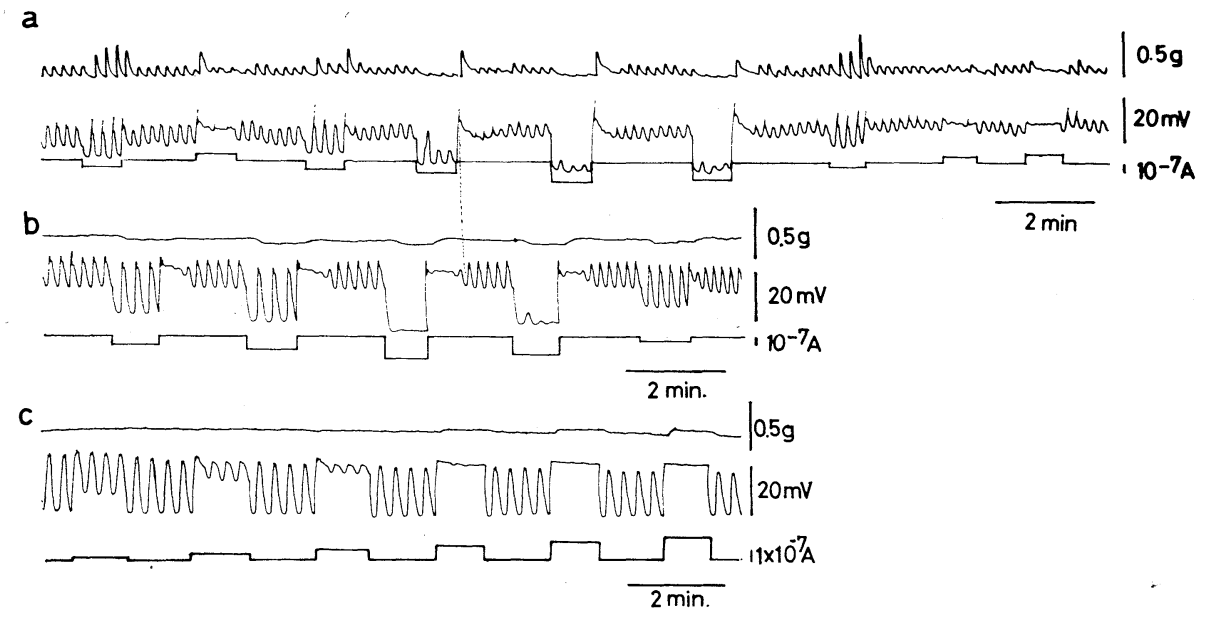

Fig. 3. Effects of inward and outward current on the electrical activity of the stomach muscle. Top trace: mechanical activity. Middle trace: electrical activity. Bottom trace: intensity of the applied current. $a$ and $b$ are taken from the same preparation.

As shown in Fig. 2, b and c, and Fig. 3, when the membrane potential was displaced in either direction using various current intensities, there was a corresponding change in the amplitude of the slow potential within a range of about $30 \mathrm{mV}$ hyperpolarization and $20 \mathrm{mV}$ depolarization. On further displacements of the membrane potential, the amplitude of the slow potential was rapidly reduced.

When the temperature was lowered to below $23^{\circ} \mathrm{C}$ from $32^{\circ} \mathrm{C}$, the membrane was depolarized $(3-8 \mathrm{mV})$ and the membrane resistance increased (1.3 times the value obtained at $32^{\circ} \mathrm{C}, n=3$ ). The slow potential changes were reduced or ceased altogether. On the other hand, when the temperature was raised from $32^{\circ} \mathrm{C}$ to $38^{\circ} \mathrm{C}$, the membrane was slightly depolarized $(3-5 \mathrm{mV})$ and the membrane resistance was reduced $\left(0.8\right.$ times the value obtained at $\left.32^{\circ} \mathrm{C}, n=3\right)$. The frequency of the slow potential changes was increased with a mean $\mathrm{Q}_{10}$ value of 3.2 $(n=5)$. Figure 4 shows the effects of environmental temperature $\left(21^{\circ} \mathrm{C}, 26^{\circ} \mathrm{C}\right.$, and $38^{\circ} \mathrm{C}$ ) on the slow potential changes. The membrane resistance was measured throughout the experiment by application of short inward current pulses. The lowest resistances of the membrane during rest and during the slow depolarization 


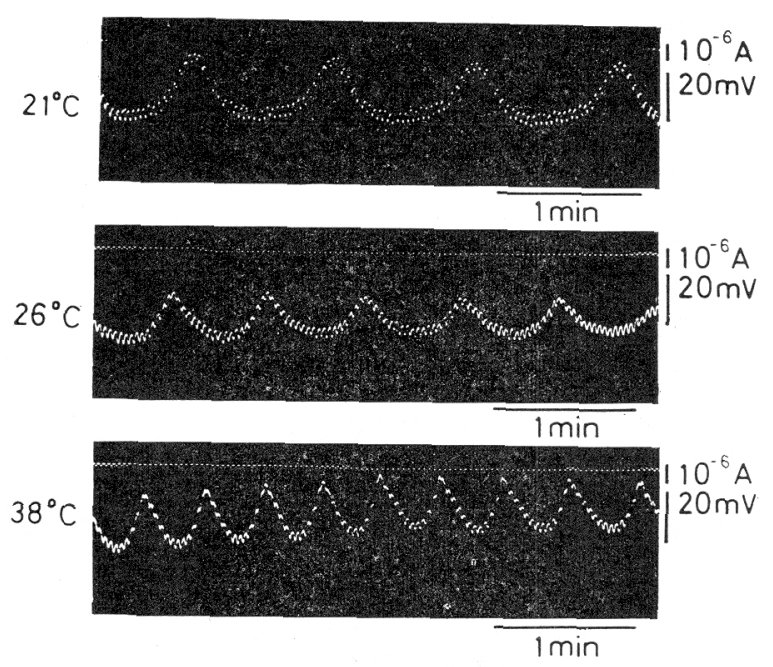

Fig, 4. Effect of temperature $\left(21^{\circ} \mathrm{C}, 26^{\circ} \mathrm{C}\right.$, and $\left.38^{\circ} \mathrm{C}\right)$ on the slow potential changes. Throughout the experiment inward current pulses $(500 \mathrm{msec})$ were applied.

of the membrane were observed at $38^{\circ} \mathrm{C}(0.7$ times the membrane resistance measured at $26^{\circ} \mathrm{C}$ ).

After storage of the circular muscle preparations in the cold $\left(6^{\circ} \mathrm{C}\right)$ for $20 \mathrm{hr}$, slow potentials with spike could be recorded. However, after more than $36 \mathrm{hr}$ storage, the circular muscle preparations did not generate slow potential changes, although spikes were elicited by application of outward current pulses. According to results derived from the microelectrode method, the membrane potential was reduced from $-58.1 \mathrm{mV}(\mathrm{SD}= \pm 2.6, n=30)$ to $-49.8 \mathrm{mV} \quad(\mathrm{SD}= \pm 3.6$, $n=30)$ after $36 \mathrm{hr}$ storage in the cold $\left(6^{\circ} \mathrm{C}\right)$.

\section{Effects of various ionic environments on the slow potential changes}

Na ion: Reduction of $\mathrm{Na}$ ion (substituted by sucrose, Li, and Tris) to half the normal concentration $(68 \mathrm{~mm})$ reduced the amplitude and frequency of the slow potential changes. The effects of $\mathrm{Na}$-deficient Krebs solution $(\mathrm{NaCl}$ being substituted by Tris $\mathrm{Cl}$ and $15.5 \mathrm{~mm} \mathrm{Na}$ ion still present as $\mathrm{NaHCO}_{3}$ ) on the membrane activity of the smooth muscle is shown in Fig. 5b. After several minutes of perfusion, the membrane was hyperpolarized (up to $12 \mathrm{mV}$ ) and the membrane resistance was reduced ( 0.6 times the control value, $n=3$ ). The slow potential changes were completely abolished, although conditioning hyperpolarization of the membrane to $10 \mathrm{mV}$ restored the slow potential changes.

A similar phenomenon was also observed in $\mathrm{LiCl}$ Krebs solution (15.5 mM $\mathrm{Na}$ ion remained as $\mathrm{NaHCO}_{3}$ ). As shown in Fig. 5d, the slow potential changes ceased in Li-Krebs solution, but weak hyperpolarizing current pulses restored the generation of the slow potential changes. The membrane resistance was only 
a

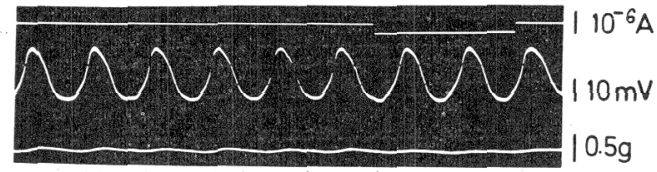

$b$

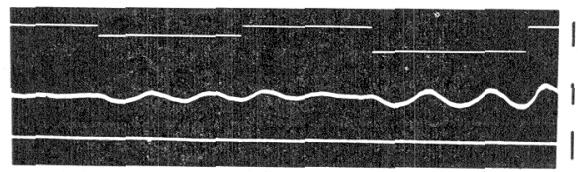

c
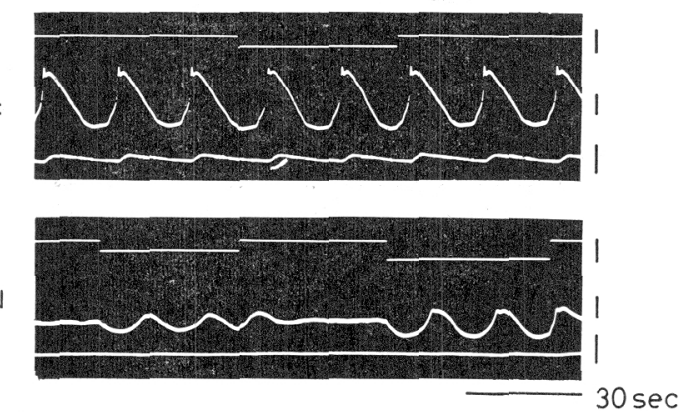

Fig. 5. Effects of Na-deficient solution on the slow potential changes: $15.5 \mathrm{~mm}$ of $\mathrm{Na}$ ion still remained as $\mathrm{NaHCO}_{3}$. (a) and (c) Control, (b) $\mathrm{NaCl}$ was replaced by Tris $\mathrm{Cl}$, (d) $\mathrm{NaCl}$ was replaced by $\mathrm{LiCl}$, Conditioning polarization was applied to the tissue.

slightly modified in Li-Krebs solution (1.1 times the control value, $n=3$ ).

In $\mathrm{Na}$-free solutions, where total $\mathrm{Na}$ was replaced by Tris, $\mathrm{Li}$, or sucrose, the slow potential changes could not be generated even during conditioning polarization of the membrane. A spike, however, could be elicited by an outward current pulse. These results suggest that in the normal condition, the generation of slow potential changes requires the presence of more than $50 \%$ of the normal concentration of $\mathrm{Na}$ ion. However, the minimum concentration needed to generate the slow potential change during displacement of the membrane potential was less than one-ninth the normal concentration $(15.5 \mathrm{~mm})$.

$K$ ion: Effects of $\mathrm{K}$-deficient and excess $\mathrm{K}$ Krebs solution on the slow potential changes were observed. After 20 min perfusion with one-tenth the normal concentration of $\mathrm{K}$ ion $(0.59 \mathrm{~mm})$, the membrane was slightly hyperpolarized (3-6 $\mathrm{mV}, n=4)$ and the membrane resistance was increased (1.3-1.4 times the control, $n=4)$. The frequency and the amplitude of the slow potential changes were lowered from 3.2 to 2.6 per min and $18 \mathrm{mV}$ to $14 \mathrm{mV}$, respectively. On the other hand, excess $\mathrm{K}$ ion $(29 \mathrm{~mm})$ depolarized the membrane $(4-7 \mathrm{mV}, n=3)$ and reduced the membrane resistance ( $0.7-0.5$ times the control, $n=3)$. The frequency of the slow potential changes was increased from 2.8 to 4.1 per min, but the amplitude was reduced. Figure 6 shows the effects of excess $\mathrm{K}$ ion $(11.6 \mathrm{~mm}$, 


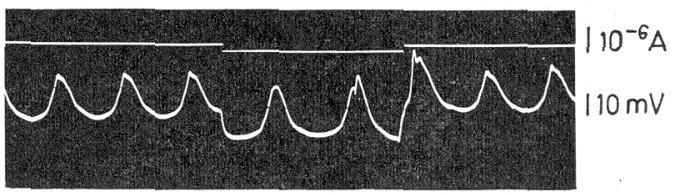

b

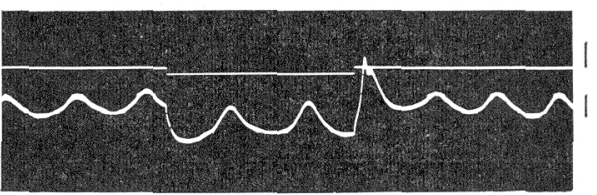

c

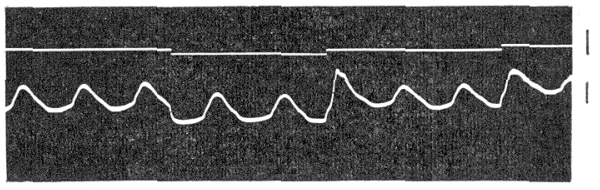

d

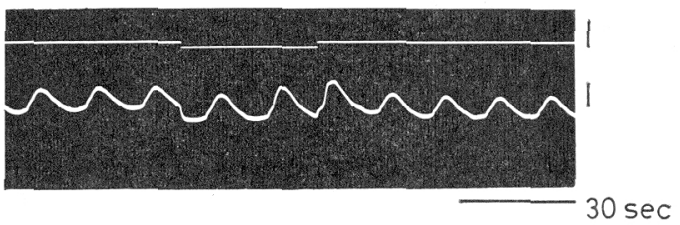

Fig. 6. Effects of excess $\mathrm{K}$ ion on the slow potential changes. (a) Control (5.9 mm K ion), (b) $11.8 \mathrm{~mm} \mathrm{~K}$ ion, (c) $17.7 \mathrm{~mm} \mathrm{~K}$ ion, (d) $23.2 \mathrm{~mm} \mathrm{~K}$ ion. Long inward current pulses were applied.

$17.4 \mathrm{~mm}$ and $23.2 \mathrm{~mm}$ ) on the frequency and amplitude of the slow potential changes.

Anions: $\mathrm{Cl}$ ion in Krebs solution was substituted by $\mathrm{C}_{6} \mathrm{H}_{5} \mathrm{SO}_{3}, \mathrm{NO}_{3}$, and $\mathrm{Br}$ ions (7.4 mM of $\mathrm{Cl}$ still remained as $\mathrm{CaCl}_{2}$ and $\mathrm{MgCl}_{2}$ ). When $\mathrm{Cl}$ ion in $\mathrm{Krebs}$ solution was replaced by $\mathrm{C}_{6} \mathrm{H}_{5} \mathrm{SO}_{3}$ ion, the membrane resistance was slightly increased (1.2-1.4 times the control, $n=3)$ but the membrane potential remained nearly the same. The slow potential change, however, was completely abolished and was not restored by conditioning polarization of the membrane. Figure 7 shows the effects of the $\mathrm{Cl}$-deficient $\left(\mathrm{C}_{6} \mathrm{H}_{5} \mathrm{SO}_{3}\right) \mathrm{Krebs}$ solution on the slow potential changes. The membrane was slightly depolarized $(3 \mathrm{mV})$, and conditioning polarization did not restore the slow potential changes (b). The membrane resistance was increased (1.3 times the control).

In $\mathrm{Cl}$-deficient $\left(\mathrm{NO}_{3}\right)$ solution, the membrane resistance was slightly decreased (0.9 times the control, $n=3$ ) and the electrical threshold needed to elicit the spike was lowered. As in the $\mathrm{C}_{6} \mathrm{H}_{5} \mathrm{SO}_{3}$-Krebs solution, the slow potential changes completely ceased and conditioning polarization failed to restore them. The effects of replacement of $\mathrm{Cl}$ ion by $\mathrm{Br}$ ion on the membrane activity were the same as that observed in the $\mathrm{NO}_{3}$-Krebs solution with slight hyperpolarization of the membrane $(3-5 \mathrm{mV}, n=5)$. The electrical threshold necessary to trigger the 
a
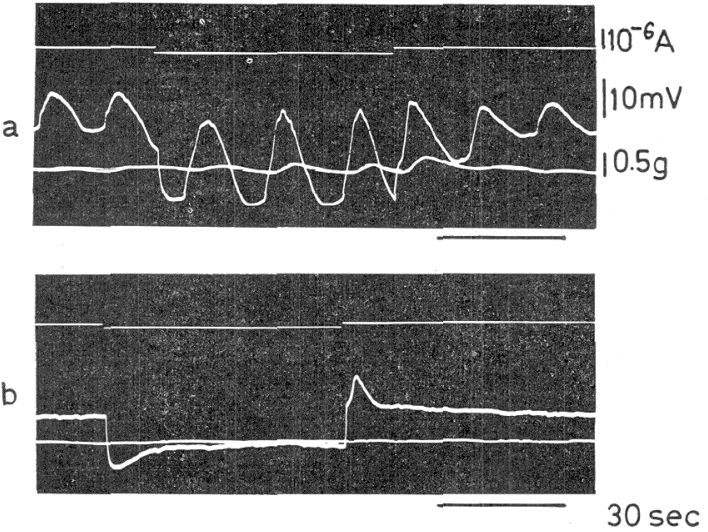

Fig. 7. Effects of $\mathrm{Cl}$-deficient Krebs solution on the slow potential changes ( $\mathrm{Cl}$ ion was replaced by $\mathrm{C}_{6} \mathrm{H}_{5} \mathrm{SO}_{3}$, but $7.4 \mathrm{~mm}$ of $\mathrm{Cl}$ still remained as $\mathrm{CaCl}_{2}$ and $\mathrm{MgCl}_{2}$ ). (a) Control, (b) After 20 min. Cl-deficient Krebs solution.

spike was also lowered. However, there were significant differences between the solutions in the slow potential changes. For instance, in the presence of $\mathrm{Br}$ ion, the slow potential change did not cease but remained at the same frequency as that in Krebs solution, and in some preparations the frequency was increased.

Divalent cations: Ca-deficient solution $(0.25 \mathrm{~mm}$, one-tenth the normal concentration) slightly depolarized the membrane $(5-7 \mathrm{mV}, n=3)$ and suppressed the spike generation. The frequency and amplitude of the slow potential changes were reduced. However, even after 30 min perfusion, the slow potential changes were not completely abolished. Although $\mathrm{Ca}$ ion was absent, the slow depolarization was completely abolished after only $15 \mathrm{~min}$ perfusion. Figure 8 shows a typical example of the effects of Ca-deficient $(0.50 \mathrm{~mm})$ solution on the slow potential changes. On the other hand, excess $\mathrm{Ca}$ ion $(7.5 \mathrm{~mm})$ hyperpolarized

a
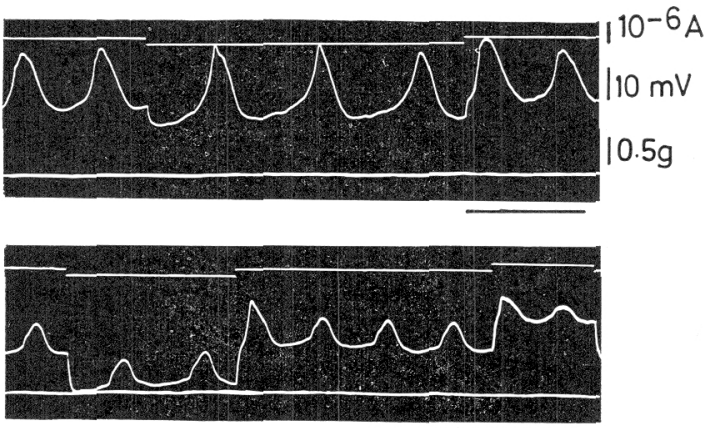

$30 \mathrm{sec}$

Fig. 8. Effects of Ca-deficient Krebs solution on the slow potential changes. (a) Control (2.5 mm Ca), (b) Ca-deficient Krebs (0.50 mm Ca), after $20 \mathrm{~min}$. 
the membrane $(6-8 \mathrm{mV}, n=3)$ and increased the membrane resistance $(1.2-1.4$ times the control, $n=3$ ). The amplitude of the slow potential changes was enhanced from $12 \mathrm{mV}$ to $18 \mathrm{mV}(n=3)$, but the frequency was reduced from 3.2 to 2.1 per $\min (n=3)$.

Three times excess $\mathrm{Mg}$ ion (3.6 mM) in Krebs solution did not produce any marked changes in the membrane potential, membrane resistance, or amplitude and frequency of the slow potential changes.

$\mathrm{Sr}$ ion could be substituted for $\mathrm{Ca}$ ion for spike generation in the antral smooth muscle, and no changes of the membrane potential and membrane resistance were observed (SAKAMOTO and KURIYAMA, 1971). However, the slow potential changes were completely abolished.

$\mathrm{Ba}$ ion in Krebs solution (below $2 \mathrm{~mm}$ ) increased the frequency, amplitude, and duration of the slow potential changes, and spikes were often generated on the slow potentials. When the concentration of Ba ion exceeded $5 \mathrm{mM}$, spontaneously generated spikes with sustained depolarization prevented the generation of the slow potential changes. In Ca-free Krebs solution, $\mathrm{Ba}$ ion at a concentration of $2.5 \mathrm{~mm}$ produced spike with sustained depolarization. Presumably, in the absence of $\mathrm{Ca}$ ion the generation of the spike and the sustained depolarization rather than the acceleration of the frequency of the slow potential changes were the dominant effects of $\mathrm{Ba}$ ion. The increased frequency and amplitude of the slow potential changes produced on treatment with $\mathrm{Ba}$ ion in Krebs solution was suppressed by atropine $\left(10^{-6} \mathrm{~g} / \mathrm{ml}\right)$. Therefore, Ba ion might act on the release mechanism of cholinergic transmitter from the nerve terminals as well as directly on the smooth muscle membrane. However, in the Ca-free Krebs solution, $\mathrm{Ba}$ ion might act predominantly on the muscle membrane and the effect on the nerve terminals might be masked by the spontaneously generated spike with sustained depolarization.

\section{Effects of various drugs on the slow potential changes}

Effects of tetrodotoxin $\left(10^{-6}-10^{-5} \mathrm{~g} / \mathrm{ml}\right)$ on the slow potential changes were not consistent. For example, in four out of eight preparations the generation of the slow potential changes was suppressed completely; in two preparations the generation was transiently suppressed, but after 10-15 min spontaneously occurred again with lower amplitude and frequency than those before the treatment; in two preparations there was no change in the amplitude or frequency of the slow potential changes.

Similar uncertainty of the drug action was also seen when this muscle preparation was treated with atropine and prostigmin.

Figure 9 shows the effects of atropine $\left(10^{-6} \mathrm{~g} / \mathrm{ml}\right)$ on the slow potential changes during pretreatment with prostigmin $\left(10^{-6} \mathrm{~g} / \mathrm{ml}\right)$. In the presence of prostigmin spikes were triggered on the slow potential changes. On treatment with atropine, however, the slow potential changes were completely abolished. 


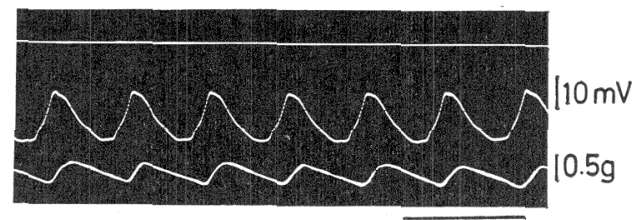

b
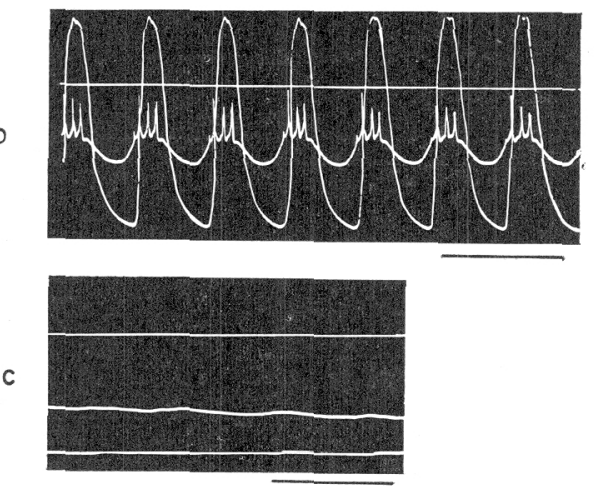

d

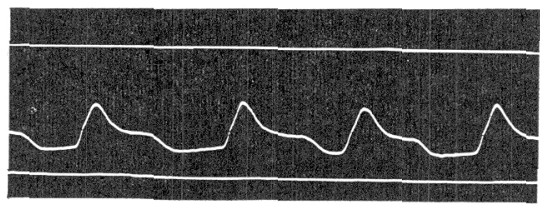

Fig. 9. Effects of atropine $\left(10^{-6} \mathrm{~g} / \mathrm{ml}\right)$ on the slow potential changes and tension development following treatment with prostigmin $\left(10^{-6} \mathrm{~g} / \mathrm{ml}\right)$. (a) Control, (b) Effect of prostigmin, (c) Effect of atropine (after 3 min perfusion with atropine containing Krebs solution), (d) Effect of atropine (after $30 \mathrm{~min}$ ).

After rinsing with Krebs solution or in the presence of atropine, the slow potential changes reappeared with low amplitude and low frequency. Readdition of prostigmin $\left(10^{-6} \mathrm{~g} / \mathrm{ml}\right)$ no longer enhanced the amplitude and frequency of the slow potential changes. In eight out of fourteen preparations prostigmin $\left(10^{-6} \mathrm{~g} / \mathrm{ml}\right)$ enhanced the frequency and the amplitude of the slow potential changes. Figure 10 also shows the effects of prostigmin $\left(10^{-6}, 2 \times 10^{-6}, 4 \times 10^{-6} \mathrm{~g} / \mathrm{ml}\right)$ on the electrical and mechanical activities of the muscle $(b-e)$. These effects were very marked and were nearly the same as those produced by acetylcholine (a). Figure $10 \mathrm{f}$ shows an example of no effect of prostigmin on the slow potential changes. However, after treatment with prostigmin the effect of acetylcholine was enhanced compared with that before the treatment. Figure $10 \mathrm{~g}$ shows that atropine $\left(10^{-6} \mathrm{~g} /\right.$ $\mathrm{ml})$ had no effect on the slow potential changes, but the effect of acetylcholine $\left(10^{-6}\right.$ $\mathrm{g} / \mathrm{ml}$ ) after treatment with atropine was completely abolished.

Several trials of application of tetrodotoxin, atropine, and prostigmin caused essentially the same effect in a given preparation. It appears that the difference 


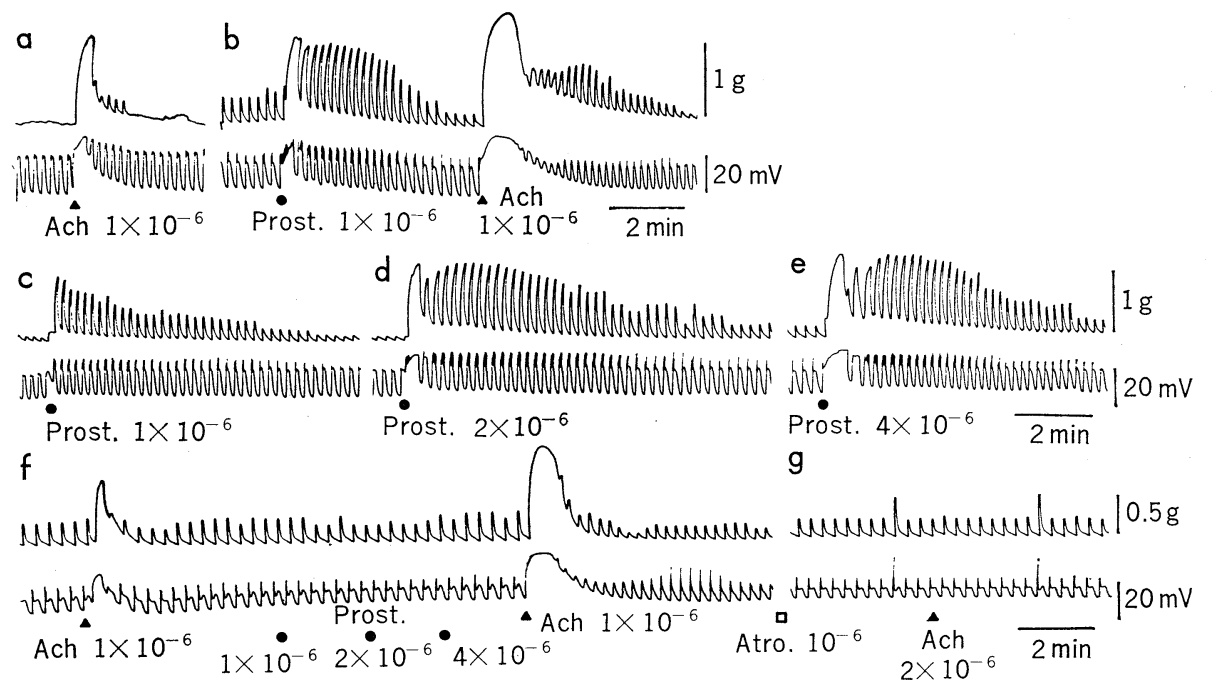

Fig. 10. Effect of various concentrations of prostigmin (Prost) $\left(1-4 \times 10^{-6} \mathrm{~g} / \mathrm{ml}\right)$ compared with acetylcholine (Ach) on the electrical and mechanical activities of the stomach muscle. Concentrations in $\mathrm{g} / \mathrm{ml}$. a-e were recorded from the same preparation, but $f$ and $g$ were recorded from a different one. Note in (f) Prostigmin did not show any effect on the slow potential changes but enhanced the effect of Ach. (g) Effect of atropine $\left(10^{-6}\right.$ $\mathrm{g} / \mathrm{ml}$ ). Atropine did not show any effect on the slow potential changes but suppressed the effect of Ach.

in the effect of these drugs was mainly due to the difference in tissues as well as animals.

It was found that the slow potential changes were composed of atropinesensitive and -insensitive components. For example, in three out of five preparations only the slow potential changes were blocked, and two preparation did not show any response to treatment with atropine. Furthermore, even the suppressed slow potential changes reappeared with low frequency and with a different shape after 30-40 min continuous perfusion of atropine-containing Krebs solution $\left(10^{-6}\right.$ $\mathrm{g} / \mathrm{ml}$ ). The observed effects of prostigmin and atropine on the slow potential changes indicate that acetylcholine is not essential to generate the slow potential changes, but it modifies them.

On treatment with acetylcholine $\left(10^{-6} \mathrm{~g} / \mathrm{ml}\right)$, the membrane was consistently depolarized and phasic contraction was evoked, although spike generation was rare. The peak amplitude of the depolarization exceeded by several $\mathrm{mV}$ the peak of the slow potential changes. When the membrane was hyperpolarized, the amplitude of the acetylcholine potentials was increased proportionally, and they were decreased during depolarization. Typical effects of acetylcholine $\left(10^{-6} \mathrm{~g} /\right.$ $\mathrm{ml}$ ) on the muscle membrane at various membrane potentials displaced by elec- 
trical currents are demonstrated in Fig. 11. These results suggested that the range of the membrane potential between which the acetylcholine potentials, like the slow potential changes, can be generated was $+20 \mathrm{mV}$ and $-30 \mathrm{mV}$ from the resting membrane potential. However, the acetylcholine potential exceeded by several $\mathrm{mV}$ the peak amplitude of the slow potential changes. In the present experiments, the reversal potential level for acetylcholine could not be estimated.
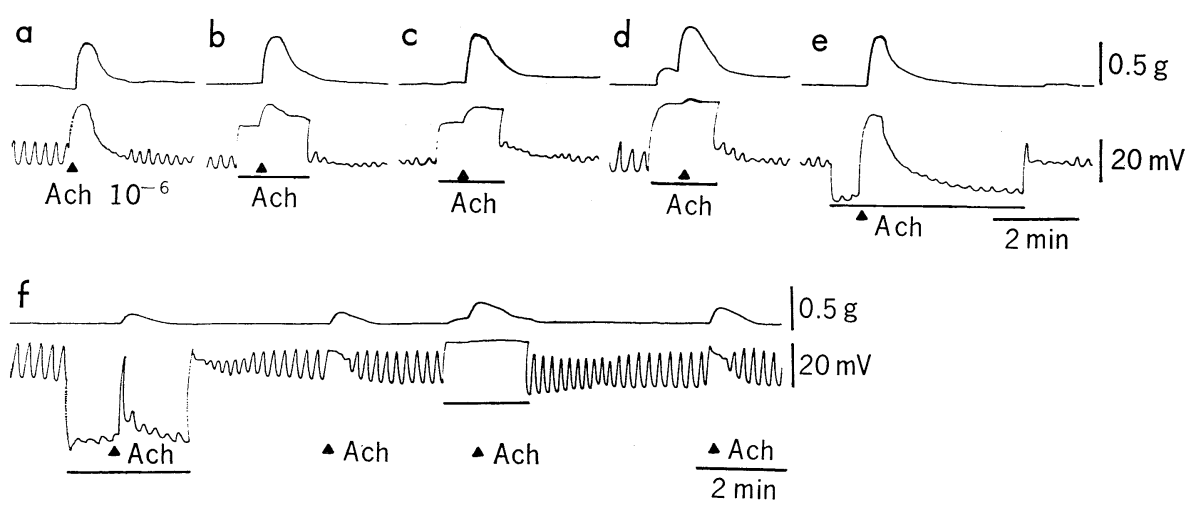

Fig. 11. Effect of acetylcholine $\left(10^{-6} \mathrm{~g} / \mathrm{ml}\right)$ during displacement of membrane potential levels by inward and outward current pulses. a-e were recorded from the same preparation, but $f$ was recorded from a different one. (a) Control, (b-e) The membrane potential levels are displaced by various intensities of inward and outward current pulses $\left(1.2-6 \times 10^{-7} \mathrm{~A}\right)$, (f) Intensities of current pulse are $7.2 \times 10^{-7} \mathrm{~A}$ (inward) and $6 \times$ $10^{-7} \mathrm{~A}$ (outward), respectively. Horizontal bars indicate the applications of the current pulse.

Effects of catecholamines (noradrenaline and isoprenaline) on the slow potential changes were observed. Noradrenaline $\left(10^{-6} \mathrm{~g} / \mathrm{ml}\right)$ and isoprenaline $\left(10^{-6} \mathrm{~g} / \mathrm{ml}\right)$ blocked or suppressed the generation of the slow potential (Fig. 12). Noradrenaline hyperpolarized the membrane, reduced the membrane resistance, and blocked the generation of the slow potential changes. Isoprenaline slightly hyperpolarized the membrane, but no change of the membrane resistance was observed. However, the amplitude of the slow potential change and phasic contraction was suppressed.

To investigate whether or not the hyperpolarization of the membrane produced by treatment with noradrenaline is the main factor in abolishing the slow potential change, conditioning hyperpolarization of the membrane to the same magnitude as that produced by noradrenaline was applied (Fig. 13c). The hyperpolarization of the membrane produced by the electrical current did not suppress the generation of the slow potential changes. Therefore, an increased ionic conductance, presumably K-conductance, may be the main reason the slow potential was suppressed by noradrenaline. 

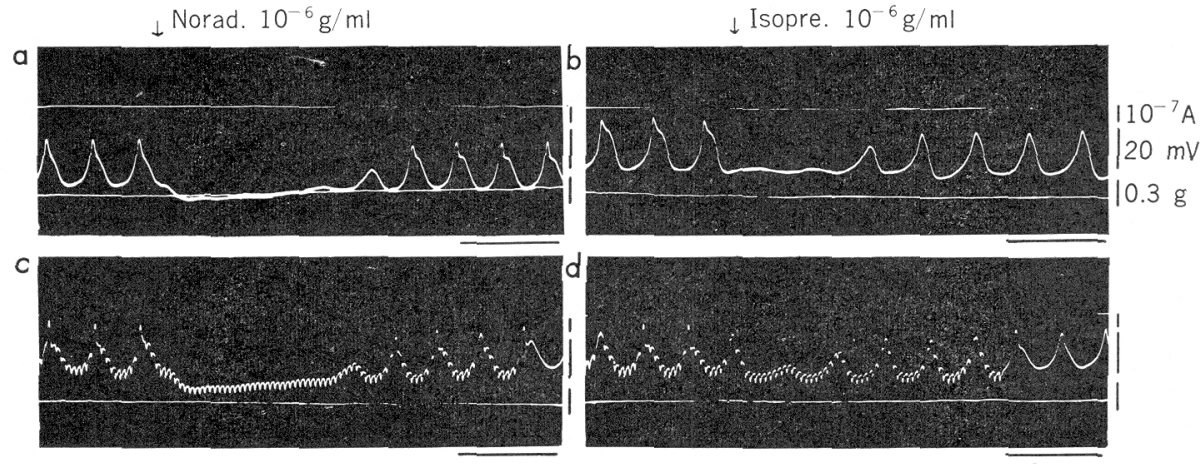

$30 \mathrm{sec}$

Fig. 12. Effects of noradrenaline (Norad) (a and c) and isoprenaline (Isopre) (b and d) on the slow potential changes and membrane resistance.

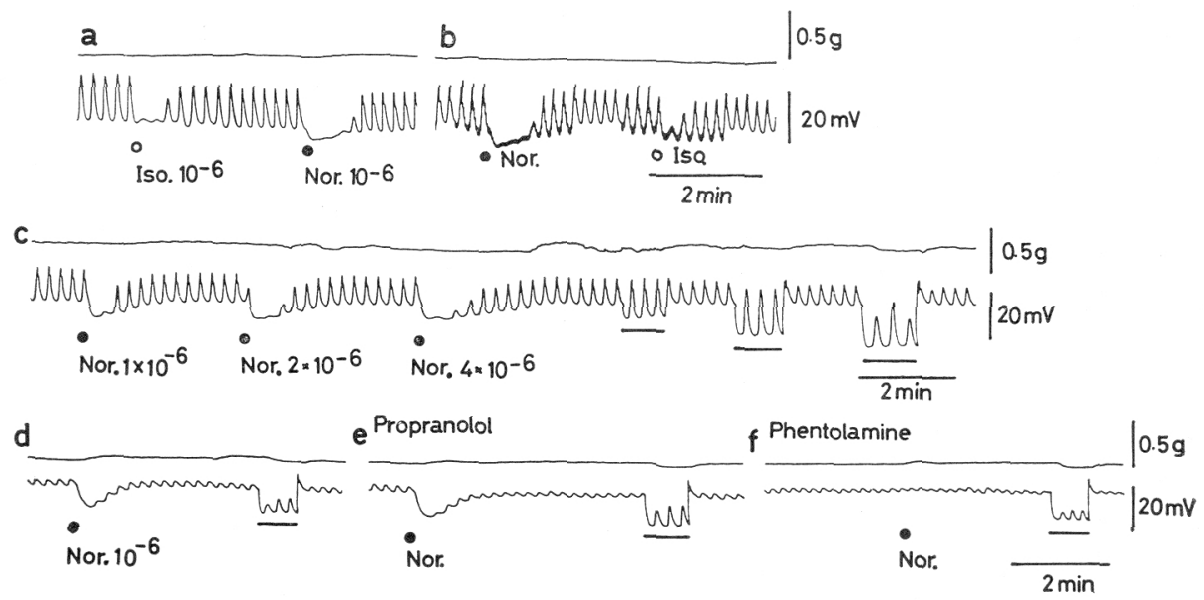

Fig. 13. Effects of noradrenaline (Nor) $\left(10^{-6} \mathrm{~g} / \mathrm{ml}\right)$ and isoprenaline (Iso) $\left(10^{-6} \mathrm{~g} / \mathrm{ml}\right)$ on the slow potential changes in comparison to conditioning polarization of the membrane (c), and the modification of their effects by propranolol $\left(10^{-6} \mathrm{~g} / \mathrm{ml}\right)(\mathrm{e})$ and phentolamine $\left(10^{-6} \mathrm{~g} / \mathrm{ml}\right)(\mathrm{f})$. Intensity of inward current pulses in (c) were $1.2 \times 10^{-7} \mathrm{~A} ; 2.4 \times 10^{-7} \mathrm{~A}$ and $4.8 \times 10^{-7} \mathrm{~A}$. Intensity in (d)-(f) was $2.4 \times 10^{-7} \mathrm{~A}$. Horizontal bars indicate applications of the current pulse.

After treatment with phentolamine $\left(10^{-6} \mathrm{~g} / \mathrm{ml}\right)$, the membrane was depolarized $(3-5 \mathrm{mV}, n=3)$ and the amplitude of the slow potential changes was reduced. Conditioning polarization of the membrane by inward current to the level before treatment with phentolamine restored the amplitude of the slow potential changes, yet noradrenaline $\left(10^{-6} \mathrm{~g} / \mathrm{ml}\right)$ and isoprenaline $\left(10^{-6} \mathrm{~g} / \mathrm{ml}\right)$ did not abolish the slow potential but only slightly suppressed the amplitude. Phentolamine $\left(10^{-6}\right.$ $\mathrm{g} / \mathrm{ml})$, but not propranolol $\left(10^{-6} \mathrm{~g} / \mathrm{ml}\right)$, blocked the effect of noradrenaline on the 
slow potential changes (Fig. 13, d-f). These effects of catecholamines on the smooth muscle might indicate that the suppression of the slow potential changes is mainly due to $\alpha$-response of the membrane. The $\beta$-response of catecholamine is weak in this membrane activity.

\section{DISCUSSION}

Recordings of spontaneous membrane activity from smooth muscles in physiological solution show that the various patterns of electrical activity depend very much on slow potential changes, namely, pacemaker type, excitatory and inhibitory potential changes evoked in response to nervous activity, the plateau potential as observed in guinea pig ureter, what is called the slow potential change with a duration of 5-10 sec with or without spiking (KurIYAmA, 1970). The slow potentials recorded from the alimentary canal are also called BER (ALVAREZ and Mahoney, 1922; Alvarez, 1948) and are a type of minute-rhythm (GolenHOFEN, 1970).

Slow potential changes have been recorded in the stomach and intestine of the dog, cat, and rabbit (Prosser and Bortoff, 1968). However, in the guinea pig the slow potential changes appear in the stomach but not in the intestine. Previous observations made on the stomach and intestinal slow potential changes can be summarized as follows: (1) the frequency of the slow potential change is characteristic for the site of the alimentary canal and is due to an inherent rhythmicity of the alimentary canal (Bozler, 1948; BortofF, 1961; Gonella, 1967; Prosser and BORTOFF, 1968); (2) the propagation of the slow potential change generated from the longitudinal muscle layer is in the longitudinal and circular directions via the circular muscle layer (BORTOFF, 1965; KoBAYASHI et al., 1966); (3) the frequency of the slow potential changes is modified by the factors of surgical procedure (Code et al., 1968), $p \mathrm{CO}_{2}$ (Golenhofen, 1970), metabolic inhibitor (DANIEL, 1965; Job, 1969), and various ions (TAMAi and Prosser, 1966; Kuriyama et al., 1967). (4) it has been reported that there are no changes of the electrical resistance of the membrane during the slow potential change (KOBAYASHI et al., 1966). However, recently SAKAMOTO and KURIYAMA (1971) and Mills and TAYLOR (1971) described changes of the membrane resistance and LIU et al., (1969) presented evidence that the form of slow potential changes is determined by an initial passive Na-influx causing a depolarization followed by an electrogenic Na-pump and passive K-efflux causing repolarization, thus suggesting that there are changes of ionic conductance during the slow potential changes. It was also shown by Bolton (1971) that slow waves in the ileal smooth muscle, which were induced by acetylcholine or carbachol, were due to Na-entry through the slow channel.

From the present results on the circular muscle of the pyloric region, it seem that the generation of the slow potential changes probably is not due to the neural transmission process. However, the cholinergic and adrenergic activity markedly 
modify the frequency and amplitude of the slow potential changes either directly or indirectly via changes in the property of the muscle membrane. Recently BECK and OsA (1971) have reported that all electrical activity of the sling muscle of the guinea pig stomach is neurogenic and direct stimulation to the muscle cannot elicit electrical activity from the muscle membrane. The properties of the circular and longitudinal muscles of stomach, therefore, differ from the sling muscle. Furthermore, slow potential changes could be generated from the isolated circular muscle layer, and the presence of the longitudinal muscle was not necessary, unlike in the intestine as described by BORTOFF (1965) and KoBAYASH et al., (1966).

A change of the membrane resistance during the slow potential was observed, indicating a change of the ionic conductance. It is also possible that there is an electrogenic pumping mechanism during the repolarization phase of the slow potential changes, as described by Jов $(1969,1971)$. The depolarization phase of the slow potential changes is thought to be related to an increase of the Napermeability. However, it is not certain whether this mechanism is a direct mechanism or is a consequence of the reduction of K-permeability.

In the giant nerve fiber of mollusc, the presence of $\mathrm{Na}-\mathrm{K}$ and $\mathrm{Na}-\mathrm{Ca}$ transport mechanisms were described by BAKER et al., (1969), BLAUSTEIN and HoDGKIN (1969). Further investigation will be required to ascertain whether or not active ion transport mechanisms are involved in the generation of the slow potential changes in stomach.

Similarities between the pace-maker activity in cardiac muscle and the slow depolarization of the stomach can be summarized as follows: (1) conditioning polarization of the membrane modified the oscillatory activity in the cardiac pacemaker muscle and slow potential change in the stomach muscle. In cardiac muscle this mechanism is thought to be due to modification of $i_{k}$ (NoBle and TsIEN, 1968, 1969; HAuswirTH et al., 1969); (2) electrical stimulation modified the frequency of the electrical activity in both tissues (pacemaker shift is discussed by Lu et al., 1968; and BonKE et al., 1969); (3) cholinergic and adrenergic drugs modified both activities; (4) changes of the environmental temperatures and stretch of the tissue also altered the frequency of the activities in both tissues $\left[\mathrm{Q}_{10}\right.$ for the pacemaker potential in sino-atrial node of rabbit is 3.2 (YAMAGISHI and SANO, 1967) and in Purkinje fiber is 6.20 (Coraboeuf and WeIdmann, 1954)]; (5) pacemaker cell in rabbit sino-atrial node and slow potential changes in stomach show low sensitivity to treatment with tetrodotoxin; (6) in the quiescent tissues of heart (auricular and ventricular muscles), $\mathrm{Ba}$ ion produced pacemaker activity which was the same as that observed in pacemaker cells (ANTONI and OBERDISSE, 1965). Ba ion also evoked slow potential changes in the quiescent circular muscle of stomach.

Recently, Rougier et al., (1969) have demonstrated the existence and role of a slow inward current during the atrial action potential. They suggested that $\mathrm{Na}$ and $\mathrm{Ca}$ ion compete through the same slow channel and generate slow action potential in the cardiac muscle. In the guinea pig stomach, the spike is due to 
inward movement of $\mathrm{Ca}$ ion, and this inward movement of $\mathrm{Ca}$ ion is thought to act competitively with $\mathrm{Na}$ ion (SAKAMOTO and KurIYAMA, 1971). It might also be possible for the competitive action of $\mathrm{Na}$ and $\mathrm{Ca}$ ion on the resting membrane to generate the slow potential changes due to periodic increase of either $\mathrm{Ca}$ influx or Na-influx. On the other hand, noradrenaline blocked the generation of the slow potential changes, mainly due to increased K-conductance, and it is unlikely that hyperpolarization of the membrane is the main factor. Presumably, such a competitive action of $\mathrm{Na}$ and $\mathrm{Ca}$ ion could be triggered by the small depolarization of the membrane which is due to reduction of K-permeability, as suggested on the pacemaker cell in cardiac muscle. Unfortunately, however, the understanding of the ionic mechanism of the slow potential changes in the smooth muscle from a theoretical basis is still far behind that of the cardiac muscle.

\section{REFERENCES}

Alvarez, W. C. (1948) An Introduction to Gastro-Enterology. 6th ed. Hoeber, New York, pp. 703-712.

Alvarez, W. C. and Mahoney, L. J. (1922) Action currents in stomach and intestine. Am. J. Physiol., 58: 476-493.

ANToni, H. and OBERDisse, E. (1965) Elektrophysiologische Untersuchungen Uber die Barium-induzierte Schrittmacher Aktivität im Isolierten Säugetiermyokard. Pflügers Arch., 284: 259-272.

Baker, P. F., Blaustein, M. P., Hodgrin, A. L., and Steinhardt, R. A. (1969) The influence of calcium on sodium efflux in squid axons. J. Physiol., 200: 431-458.

BASS, P. (1965) Electric activity of smooth muscle of the gastrointestinal tract. Gastroenterology, 49: 391-394.

BeCK, C. S. and OsA, T. (1971) Membrane activity in guinea pig gastric sling muscle; a nervedependent phenomenon Am. J. Physiol., 220: 1397-1403.

Berger, W. (1963) Die Doppelsaccharosetrennwandtechnik: Eine Methode zur Untersuchung des Membranepotentials und der Membraneigenschaften glatter Muskelzellen. Pflügers Arch., 277: 570-576.

Blaustein, M. P. and Hodgkin, A. L. (1969) The effect of cyanide on the efflux of calcium from squid axons. J. Physiol., 200: 497-527.

Bolton, T. B. (1971) On the nature of the oscillations of the membrane potential (slow waves) produced by acetylcholine or carbachol in intestinal smooth muscle. J. Physiol., 216: 403-418.

Bortoff, A. (1961) Slow potential variations of small intestine. Am. J. Physiol., 201: 203208.

Bortoff, A. (1965) Electrical transmission of slow waves from longitudinal to circular intestinal muscle. Am. J. Physiol., 209: 1254-1260.

Bortoff, A. (1967) Configuration of intestinal slow waves obtained by monopolar recording techniques. Am. J. Physiol., 213: 157-162.

Bozler, E. (1948) Conduction, automaticity and tonus of visceral muscles. Experientia, 4: 213-218.

Brading, A., Bülbring, E., and Tomita, T. (1969) The effect of sodium and calcium on the action potential of the smooth muscle of the guinea-pig taenia coli. J. Physiol., 200: 637654. 
Bonke, F. I. M., Bouman, L. N., and van Rijn, H. E. (1969) Change of cardiac rhythm in the rabbit after an atrial premature beat. Circ. Res., 24: 533-544.

Bülbring, E. F. R. S. and TomitA, T. (1969) Effect of calcium, barium and manganese on the action of adrenaline in the smooth muscle of the guinea-pig taenia coli. Proc. R. Soc. B., 172: $121-136$.

Code, C. F., Szurszewski, J. H., Kelly, K. A., and Smith, I. B. (1968) A concept of control of gastrointestinal motility. In Handbook of Physiology, Sec. 6. Alimentary Canal. Am. Physiol. Soc., Washington, D. C., pp. 2881-2896.

Coraboeuf, E. and Weidmann, S. (1954) Temperature effects on the electrical activity of Purkinje fibres. Helv. Physiol. Acta, 12: 32-41.

DANIEL, E. E. (1965) Effects of intra-arterial perfusions on electrical activity and electrolyte contents of dog small intestine. Can. J. Physiol. Pharmacol., 43: 551-577.

Golenhofen, K. (1970) Slow rhythms in smooth muscle (Minute-rhythm). In Smooth muscle, ed. by Bülbring, E., Brading, A. F., Jones, A. W., and Tomita, T. Edward Arnold, London, pp. 316-342.

Gonella, J. (1967) Étude Électrophysiologique de la Motricité intestinale. Thesis for Doctur és Sciences Naturelles.

Hauswirth, O., Noble, D., and Tsien, R. W. (1969) The mechanism of oscillatory activity at low membrane potentials in cardiac Purkinje fibres. J. Physiol., 200: 255-265.

Joв, D. D. (1969) Ionic basis of intestinal electrical activity. Am. J. Physiol., 217: 1534-1541.

Jов, D. D. (1971) Effect of antibiotics and selective inhibitors of ATP on intestinal slow waves. Am. J. Physiol., 220: 299-306.

Kobayashi, M., Nagai, T., and Prosser, C. L. (1966) Electrical interaction between muscle layers of cat intestine. Am. J. Physiol., 211: 1281-1291.

KuriYAMA, H. (1970) Effects of ions and drugs on the electrical activity of smooth muscle. In Smooth muscle, ed. by Bülbring, E., Brading, A. F., Jones, A. W., and Tomita, T. Edward Arnold, London, pp. 334-395.

Kuriyama, H., Osa, T., and TASAKI, H. (1970) Electrophysiological studies of the antrum muscle fibres of the guinea pig stomach. J. Gen. Physiol., 55: 48-62.

Kuriyama, H., OsA, T., and ToIDA, N. (1967) Nervous factors influencing the membrane activity of intestinal smooth muscle. J. Physiol., 191: 257-270.

Kuriyama, H. and Tomita, T. (1970) The action potential in the smooth muscle of the guinea pig taenia coli and ureter studied by the double sucrose-gap method. J. Gen. Physiol., 55: 147-162.

LiU, J., Prosser, C. L., and Job, D. D. (1969) Ionic dependence of slow waves and spikes in intestinal muscle. Am. J. Physiol., 217: 1542-1547.

Lu, H., LANGe, G., and Brooks, MCC. (1968) Effects of ions of sinoatrial node to stretch. Abstr. Congr. Int. Union Physiol. Sci., No. 814, Washington, D. C.

Magaribuchi, T., Ito, Y., and Kuriyama, H. (1971) Effects of catecholamines on the guinea-pig vas deferens in various ionic environments. Jap. J. Physiol., 21: 691-708.

Mills, R. G. and TaYlor, G. S. (1971) Studies of intestinal slow wave activity with a double sucrose gap apparatus. Life Sci., 10: 347-353.

Noble, D. and Tsien, R. W. (1968) The kinetics and rectifier properties of the slow potassium current in cardiac Purkinje fibres. J. Physiol., 195: 185-214.

Noble, D. and Tsien, R. W. (1969) Reconstruction of the repolarization process in cardiac Purkinje fibres based on voltage clamp measurements of membrane current. $J$. Physiol., 200: 233-254.

Papasova, M. P., Nagai, T., and Prosser, C. L. (1968) Two-component slow waves in smooth muscle of cat stomach. Am. J. Physiol., 214: 695-702.

Prosser, C. L. and Bortoff, A. (1968) Electrical activity of intestinal muscle under in vitro 
conditions. In Handbook of Physiology, Sec. 6. Alimentary Canal, Am. Physiol. Soc., Washington, D. C., pp. 2025-2050.

Rougier, O., Vassort, G., Garnier, D., Gargouil, Y. M., and Coraboeuf, E. (1969) Existence and role of a slow inward current during the frog atrial action potential. Pflügers Arch., 308: 91-110.

SaKamoto, Y. and Kuriyama, H. (1971) The relationship between the electrical and mechanical activity of the guinea-pig stomach. Jap. J. Physiol., 20: 640-656.

TAMAI, T. and Prosser, C. L. (1966) Differentiation of slow potentials and spikes in longitudinal muscle of cat intestine. Am. J. Physiol., 210: 452-458.

YAMAGISHI, S. and SANO, T. (1967) Effect of temperature on pacemaker activity of rabbit sinus node. Am. J. Physiol., 212: 829-834. 